\title{
MIKHAIL GORBACHEV, THE HUMAN FACTOR, AND THE IMPLOSION OF THE SOVIET UNION ${ }^{1}$
}

DANIELA PEREIRA NUNES

daniela pn12@hotmail.com

She has a Master in Political Science and International Relations at the Institute of Political Studies, Catholic University of Portugal (Portugal) and bachelor's in Political Science and International Relations. The main areas of interest are the Cold War, the history of the Soviet Union, and political leadership.

\section{Introduction}

Mikhail Gorbachev's unique contribution to the final balance of the Cold War and to the process that culminated simultaneously in the implosion of the Soviet Union and the failure of Soviet communism has motivated and continues to motivate scholars to think about the impact one man can have in the course of certain political processes. In the case of the Soviet Union and its disruptive process, the decisive influence of the political leader, Gorbachev, on the tragic outcome of the attempt at economic, social, and political reform seems evident. It is clear that a number of other factors, namely structural ones, influenced the events of 1985-1991, both inside and outside the Soviet Union. However, this reflection will focus on Gorbachev's role, his choices, and the limits imposed on him by the very nature of the regime he had tried to reform since 1985.

2021 will mark the 30th anniversary of the demise of the Union of Soviet Socialist Republics (USSR). Three decades after the implosion of this septuagenarian empire, Mikhail Gorbachev continues to mirror the dual debate that soon after 1991 divided historians and analysts with regard to the impact that the last Soviet leader had on this disruptive process. This debate essentially opposes two positions, which find expression in William Taubman's terminology: "[Gorbatchev] is a tragic hero" (Taubman, 2018: 693) who, to free the Soviets and East Europeans from fear, let a country and an ideology fail. However, and despite this dichotomy, there seems to be some consensus among scholars about the importance and the protagonism played by Gorbachev for the Cold War to end when and as it did. Compared to any other Soviet leader, he was the first and only one

\footnotetext{
${ }^{1}$ Note translated by Cláudia Tavares.
} 
who had a major interest in encouraging the end of this conflict, whether one interprets this as a great achievement or as a sign of his weakness.

Gorbachev's unique contribution to the final balance of the Cold War is especially appreciated in the Western World, which can see in him a visionary, someone who sought to transform a country and system that was enormous but too small for his worldview and innovative mindset. In his homeland, however, Gorbatchev is rather seen as a presumptuous utopian, betrayed by his own overconfidence, and responsible for the extermination of a seventy-year-old people and nation.

\section{The Human Factor as an Explanatory Element}

Before any further considerations about the role of this leader in the process that culminated simultaneously in the breakup of the Soviet Union, the demonstration of the failure of an ideology and the end of the Cold War, it is necessary to underline the pertinence associated with the exercise of looking at the human factor as one of the explanatory elements of these events. The narratives of major historical events and major political transitions in the world of modernity seem to reflect a tendency to link to these events explanations that are mainly inserted in the domain of structural factors. Unlike contingent factors, structural factors usually underlie broader, systemic-level interpretations, as opposed to interpretations that are extremely focused on a particular explanatory element, such as a political leader.

In the case of the Soviet Union and its implosion process, the main structural explanatory elements are related, on the one hand, to the constraints inherent to the Cold War and, on the other hand, to the characteristics of the Soviet regime itself. The bipolar balance of power in the second half of the 1980s, as one of these major structural elements, was responsible for the gradual strangulation of Soviet capabilities, mainly economic ones. In measuring forces with the rival superpower, the depletion of these capabilities would eventually lead to the Soviet system no longer being able to respond to military, technological, and space competition. At the same time, the rigidity and centralism typical of this totalitarian regime, as well as its status as a multinational state and its chronic inefficiency, also largely contributed to the tragic outcome that followed the implementation of a plan to reform the country.

Alternatively, and although we cannot reduce the problematic of the collapse of any regime or political system to a one-dimensional analysis, this reflection will concentrate on a very concrete contingent explanatory factor: Mikhail Gorbachev, his mistakes, and triumphs, in the seven years of his leadership (1985-1991). Russian history provides particularly illustrative examples, which help to understand the importance of the human factor in the unfolding of certain political processes. Sociologist Andrus Park recalls that

one of [this history's] tasks seems to be to remind humanity again and again how important individuals are in history. Ivan the Terrible, Peter the Great, Vladimir Lenin, Joseph Stalin, and many others proved in different ways that the actions of political leaders can significantly influence the course of events. (Park, 1992: 47) 
The purpose of this reflection is not, however, to compare the legacy of Gorbachev with that of the individuals listed by Park. Nor is it the intention to demonstrate that all political processes are equally influenced by the leaders who spearhead them. Rather, it is about showing how a leader can have a crucial impact on a given political process and, in particular, how Gorbachev was so important, even decisive, in the historical-political process that reflects both his unusual courage and strategy, for some, and the exhaustion of all his forces, for others.

The first sign that this leader would eventually mean some change for his country although it was impossible to predict what kind of change - was his appointment, on March 11, 1985, to the post of General Secretary of the Communist Party of the Soviet Union (PCUS). Rather than the continued power of the party's geriatric figures, this nomination reflected the recognition of the need to elect a young, open, and energetic mind. Still, this was not the most important sign of the change that Gorbachev would implement in the Soviet Union (and in the world): the most important was the way he tried to implement that change, the paths he chose to take, and those he did not choose, to make that change possible. Unlike his predecessors, he did not seek to transform the Soviet system overnight, just as he did not seek to continue the old practice of the total uniformization of Soviet society in search of a "single Soviet people" - Sovetskii Narod (Smith, 1992: 9-10).

As much or more than for his ideas, Gorbatchev distinguished himself by the way he tried to implement them, by the way, somewhat strange for a Soviet leader, he proved to always put himself in the other's shoes. These ideas, together with the way in which they were put into practice, make Gorbachev the kind of leader that Robert Tucker so faithfully summarized:

(...) someone who seeks to make the existing order successful by introducing changes to it, and who recognizes that these changes must be gradual, since they involve moving away from ways of thinking and acting that have been culturally standardized over decades. (Tucker, 1995: 159-160)

The great transformations made possible by this leader became historic not only because they reoriented the course of history at the end of the 20th century, but mainly because of the peaceful and gradual way in which they were made. Not all leaders are responsible for these kinds of transformations; some are not responsible for any transformations. All leaders therefore have what Joseph Nye classified as "varying degrees of impact on history" (Nye, 2008: 8). When working under the dome of a totalitarian regime, such as the Soviet one, the weight that a particular political leadership can have is further enhanced. As British expert Archie Brown has observed, "the incentive for a leader to be the big decision-maker is even greater, and its consequences even more dangerous, within authoritarian and totalitarian regimes." (Brown, 2014: 22).

In these regimes, it is usual to see the rise of leaders who channel their supreme power and position toward imposing their will and the cult of their personality. On the contrary, Gorbachev, as one of these great decision-makers, chose to channel his power not into the implosion of his own country, obviously, but into the end of the Cold War not for the 
sacrilege of the Warsaw Pact, but for the autonomisation of the East-European societies, not for the weakening of the Soviet position in the international political game, but for the negotiation for a denuclearized world. Perhaps the main consequence of his reformist project was not the disappearance of the Soviet Union, but the disappearance of fear, which he managed to replace peacefully by a set of opportunities, once belonging to a sphere of impossible things for both Soviets and East Europeans.

\section{From Reforms to Collapse}

When he comes to power, Gorbatchev is a reformer, but a reformer within the limits of the system itself. This is why his intention to reform Soviet communism cannot be confused with a plan to replace it. For the same reason, one should also not overly romanticize the project of this leader, whose main purpose was to recover the purity of the Marxist-Leninist nature of the Soviet system. Despite his unequivocal admiration for certain Western values, such as freedom and democracy (although we must observe these within the understanding of one who was brought up in Soviet structures), Gorbachev is a man who grows up inside communism and it is by his devotion to communism that he comes to power. It is therefore not possible to say that his reform project reflected an attempt to replace the prevailing system in the USSR. Rather, this project reflected an attempt to return to Leninism, which is particularly manifest from the economic point of view - Perestroika was nothing more than a proposal similar to Lenin's New Economic Policy in the 1920s, which aimed to stimulate, accelerate and (slightly) modernize the Soviet economy.

With Gorbachev, the attempt at economic reform was coupled with the ambition to introduce into Soviet society - highly embedded in the logic of corruption, clientelism and apathy - the spirit of openness and transparency of which Glasnost is a symbol. It is from this and other ambitions very characteristic of Gorbachev's leadership that it becomes clear that this leader's will was simply to make the Soviet Union a "normal country," (Gaspar, 2016: 98) using Carlos Gaspar's expression. It is precisely because of these ambitions, coupled with the unbridled belief in the reformability of the Soviet system, that the collapse of the USSR is in part also due to Gorbachev.

The generation of politicians from which Gorbachev emerges goes back to the Khrushchev years and to an early moment when what can be called a post-Stalinist paradigm was instituted in the Soviet Union. Krushchev's secret speech at the XX Congress of the PCUS in February 1956 warned for the first time a generation of young people - "the children of the XX Congress," (Brown, 1996: 39-40) as this generation was known - to the regime of terror that had been Stalinism. Gorbachev is one of the sons of this generation, an inescapable symbol of the impact that Khrushchev's revelations had on the process of questioning and introspection that a group of intellectuals would provide from the second half of the 1950s.

It is this process of questioning, coupled with a sense of communist purpose renewed by Khruschev's revelations, that underlies the reformist faith of Gorbachev and others of his generation. But this belief in the possibility of reforming the Soviet regime only by improving the existing system has always placed the experts in a somewhat paradoxical situation: Gorbachev's reform project reflects a laudable attempt to transform a closed 
and decadent system, but his reaction to the unforeseen consequences of this project made him responsible for the disappearance of a country and a zone of influence considered since World War II as the "Soviet political backyard" (Brown, 2020: 276-277) - Eastern Europe. The controversy attached to this leader's name lies precisely in this paradox: in order to reinvigorate Soviet communism, Gorbachev had lost the reins, allowing everyone, inside and outside the Soviet Union, to choose their own way, even if it meant the failure of all his ambitions and the naive belief that it would be possible to reform an unreformable system.

Whether in the process of fragmentation, and finally extinction of the USSR, or in the process of the de-satelitization of Eastern Europe, Gorbatchev chose to be an observer, rather than a dictator. The best way to recognize him as such is by comparing him to his predecessors - preferably by imagining what the latter would have done in his place. Like Stalin, Brezhnev, or all the others, Gorbachev had the weapons and the power to stop these processes: he could have had the first publicly critical Perestroika arrested; he could have given orders to kill everyone who tried to cross the Berlin Wall; he could have prevented the rise of Boris Yeltsin; he could have used force to put down the first nationalist demonstrations in the Baltic Republics. The most striking decisions of this leader were, as Anne Applebaum noted, those that he did not make (Applebaum, 2011). The recognition due to him is mainly justified by these decisions never taken and the way in which an authentic product of the Soviet regime chose to distance himself from the model of a typical Soviet leader.

Within the Soviet Union, and strangely enough, Gorbachev seems never to have been truly recognized for the unprecedented possibilities he offered the Soviets, allowing them to combat their natural and entrenched apathy since Czarism. In the history of Soviet leadership, Gorbachev was the only one who tried to give the Soviets everything that all his predecessors tried to take away from them: choices. Even if the consequences of these choices betrayed the true goals of this leader, he should be recognized for the fact that he chose to distance himself from the gloomy model of a typical Soviet leader. And this detachment did not manifest itself only from a political point of view. It also manifested itself in unusual ways in the context of the Soviet totalitarian summit: what other Soviet leader showed himself as concerned about ecological and environmental issues as Gorbatchev did? What other Soviet leader would choose to observe, rather than violently prevent, the liberation of the East European peoples as Gorbatchev did? What other Soviet leader would publicly accompany his wife as Gorbatchev did, with Raíssa? In part, it is these moments of detachment and uniqueness that show that everything would have been different in the Soviet Union and the world of the second half of the 1980 s if it had not been for Gorbachev coming to power in 1985. His appointment accelerated a process of implosion and liberation that would certainly come to pass years later. However, had it not been for Gorbachev and the acceleration he brought about, it is possible that this process would not have been so peaceful, and this is only due to him.

More than transforming the Soviet system, Gorbachev sought to transform the system he inherited from a set of leaders overly concerned with the maintenance of their power and the cult of their personality. Within his Marxist convictions, this leader's priorities were quite distinct from those of his predecessors: instead of a sphere of influence, he sought to build a global order based on cooperation; instead of standardization, he sought 
to give everyone their own voice; instead of force, he sought to use words. Ultimately, and paradoxically, it can be said that Gorbachev's reformist plans resulted not in the deepening of his country's legitimacy and power, but rather in its erosion, which finally culminated in its ultimate demise. As emphasized at the beginning of this reflection, several external forces actively contributed to this outcome - first of all, the successive loss of means to maintain the level of competition with the rival superpower. But it was the domestic forces that made such a rapid implosion possible: Gorbachev created more enemies inside his country than outside, underestimating all along the hatred of these enemies, some of them figures who were quite close to him.

Of course, Gorbatchev is primarily responsible for his mistakes, for the decisions he made and those he did not make. But one must see in his political course a courageous attempt to assume and try to correct the flaws of an incorrigible system. Likewise, one must understand, as noted by Russian expert Vladislav Zubok, that "(...) no one knows how to transform a totalitarian regime, and therefore it can only be done by trial and error" (Zubok, 2007: 313-314). Only after a first attempt at reform - Perestroika - was it possible to realize that, in addition to a transformation of its economic model, the Soviet Union needed to be transformed culturally and socially. The shift from Gorbachev's reformist project to a system-level transformation results not from the leader's incapacities, but from the chronic deficiencies of the regime itself. What this means is that the plan to reform this regime only became radicalized as the regime itself demonstrated its chronic inability to adapt to a set of innovative ideas.

Only those who have the ability to see in Gorbachev the figure of a liberator, responsible for progress that no other Soviet leader has ever been interested in, understand how the human factor is fundamental in explaining the implosion of the USSR and the last seven years of the Cold War. Those who, on the other hand, see in this leader the figure of a traitor, will tend to consider that he simply gave in to internal and external pressure. For the latter analysts, it is hard to see anything heroic in Gorbachev's choices and concessions. But it must be stressed that, like all his predecessors, Gorbachev had all the power in his hands; unlike all of them, however, he chose to limit it. No element extraneous to a leader's personality, education and training can explain this - this is where the relevance of the human factor lies.

\section{References}

Applebaum, Anne (2011). "The Long, Lame Afterlife of Mikhail Gorbachev." Foreign Policy. (Online). Available at: https://foreignpolicy.com/2011/06/20/the-long-lameafterlife-of-mikhail-gorbachev/ (Consulted on January 30, 2021).

Brown, Archie (1996). The Gorbachev Factor. Oxford: Oxford University Press.

Brown, Archie (2014). The Myth of the Strong Leader: Political Leadership in the Modern Age. New York: Basic Books.

Brown, Archie (2020). The Human Factor: Gorbachev, Reagan and Thatcher, and the End of the Cold War. Oxford: Oxford University Press.

Gaspar, Carlos (2016). O Pós-Guerra Fria. Lisboa: Tinta da China. 
Nye, Joseph S. (2008). The Powers to Lead. Oxford: Oxford University Press.

Park, Andrus (1992). "Gorbachev and the Role of Personality in History." Studies in Comparative Communism. XXV ( $\left.n^{\circ} 1\right)$ : 47-56.

Smith, Graham (1992). "Nationalities Policy from Lenin to Gorbachev." In Graham Smith (ed), The Nationalities Question in the Soviet Union. Essex: Longman, 1-20.

Taubman, William (2018). Gorbachev: His Life and Times. New York: W. W. Norton \& Company.

Tucker, Robert C. (1995). Politics as Leadership. Missouri: University of Missouri Press.

Zubok, Vladislav (2007). A Failed Empire: The Soviet Union in the Cold War from Stalin to Gorbachev. North Carolina: The University of North Carolina Press.

\section{How to cite this note}

Nunes, Daniela Pereira (2021). Mikhail Gorbachev, the human factor, and the implosion of the Soviet Union. Notes and Reflexions. Janus.net, e-journal of international relations. Vol12, No. 1, May-October 2021. Consulted [online] at date of last visit, https://doi.org/10.26619/1647-7251.12.1.01

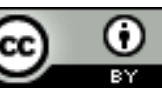

